\title{
Integrating Plant Nutrients and Elicitors for Production of Secondary Metabolites, Sustainable Crop Production and Human Health: A Review
}

\author{
Ávila-Juárez Luciano*, Torres-Pacheco Irineo, Ocampo-Velázquez Rosalía Virginia, Ana Angélica Feregrino-Pérez, \\ Andrés Cruz Hernández and Guevara-González Ramón Gerardo* \\ Biosystems Engineering Group, Division of Graduate Studies, School of Engineering, Universidad Autónoma de Querétaro, \\ C.U Cerro de las Campanas, S/N, Colonia Las Campanas. C.P. 76010. Santiago de Querétaro, Querétaro, México
}

"For correspondence: ramon.guevara@uaq.mx

\begin{abstract}
Plants are essential sources of bioactive substances that promote health. For economic reasons, farmers usually focus on obtaining higher yields rather than crop nutraceutical quality. The application of non-essential elements (NEEs) is a technique used to increase secondary metabolites (SMs) in plants. This technique includes variations of the essential elements ratios in a nutrient solution or the inclusion of elicitors, such as salicylic acid or methyl jasmonate. Elicitor use is controversial because plants grow differently in inert substrates, in vitro and soil. Soil contains essential elements (EEs) and NEEs that can enhance SM synthesis and increase nutraceutical plant quality. However, any technique that modifies plant metabolism can decrease yields. Thus, developing techniques to increase both agricultural product yield and quality is necessary. This review aims to demonstrate the necessity for a new recipe or "cocktail" of plant nutrients based on EEs and NEEs, and elicitors apply to achieve both a high yield and crops nutraceutical quality. (C) 2017 Friends Science Publishers
\end{abstract}

Keywords: Elicitors; Essential chemical elements; Non-essential chemical elements; Secondary metabolites

\section{Introduction}

Since the "Green Revolution," agriculture has been influenced by land mechanization, genetically improved crops, and the excessive use of fertilizers and pesticides which are harmful to the environment (Floros et al., 2010). Such changes have increased agricultural yields (Dayan et al., 2009) because of the more rapid growth of crops (Stefanelly et al., 2010). Moreover, improved plant care and optimal climate handling have improved the conditions for plant growth (Bennett et al., 2012) and reduced the production of secondary metabolites (SMs).

Plants are an essential source of nutrients and secondary metabolites (SMs) (Patra et al., 2013), frequently referred as bioactive compounds, such as alkaloids, phenolic compounds (PCs) and terpenes (Jahangir et al., 2009). Certain SMs reduce the risk of disease, including colon cancer (Russell and Duthie, 2011) and, reduce blood pressure, serum lipids, diabetes mellitus, obesity (PerezVizcaino and Duarte, 2010) and cardiovascular diseases (Bernal et al., 2011).

Organic products contain additional SMs when compared with conventional products. The main difference between organic agriculture (OA) and conventional agriculture (CA) is that former uses more plant-friendly pesticides with lower residual effect, with crop growth medium as soil. Soil contains essential (EEs) and non- essential elements (NEEs) in inadequate ratios for plant nutrition, and under stress conditions, plants produce more SMs (de Costa et al., 2013). Moreover, SMs alter normal growth, resulting in decreased crop yields. However, organic products have better nutraceutical quality, but OA cannot always satisfy the demand for horticultural products because a) certain crop yields are approximately $30 \%$ of the obtained in CA (Ramos-Solano et al., 2010) and b) OA occupies less than $5 \%$ of the cultivable land (Connor, 2008).

Currently, various techniques are being used to increase SMs in plants, including varying ratios of EEs or adding NEEs in the nutrient solution (NS), soil or directly to the plant and applying elicitors such as jasmonic acid (JA), salicylic acid (SA) or nitric oxide (NO) and their derivatives. However, there is a risk of causing an increase or decrease in the yield and SM production by the use of these techniques. The application of elicitors is a widely used technique. However, the SM production in plants growing in soil, in vitro or in inert substrates varies, with more SMs usually produced in soil.

In a broad sense, "elicitor", for a plant refers to chemicals from various sources that can trigger physiological and morphological responses (Zhao et al., 2005). For instance: methyl jasmonate (MeJ) (Heredia and Cisneros-Zevallos, 2009), JA (Saw et al., 2010), SA, and hydrogen peroxide $\left(\mathrm{H}_{2} \mathrm{O}_{2}\right)$ (Jeong and Park, 2005) act as elicitors. Elicitors mimic the action of plant signaling

To cite this paper: Ávila-Juárez, L., I. Torres-Pacheco, R.V. Ocampo-Velázquez, A.A. Feregrino-Pérez, A. CruzHernández and R.G. Guevara-González, 2017. Integrating plant nutrients and elicitors for production of secondary metabolites, sustainable crop production and human health: A review. Int. J. Agric. Biol., 19: 391-402 
molecules (Ruiz-García and Gómez-Plaza, 2013) and produce reactive oxygen species (ROS) (Yoshioka et al., 2011) that stimulate the plant to produce defense hormones and enzymatic or non-enzymatic antioxidant mechanisms to mitigate ROS effects. A similar effect is caused in the soil by NEEs.

Therefore, the agricultural industry should focus on obtaining high yields with greater nutraceutical quality to promote public health. In the present review, we present the relationship of EEs and certain NEEs in SM production and review the application of elicitors in plants cultivated in soil, inert substrates or in vitro and the relationship between elicitors, EEs and NEEs on secondary metabolite production in plant.

\section{Sustainable Agriculture}

Current agriculture practices require a shift towards sustainability models. Plant nutrition should focus on obtaining high yields and crops with greater nutraceutical value usually high in SMs than what are currently produced. Plants grown under OA conditions contain more SMs than produced under CA (Vallverdú-Queralt et al., 2012). Amendments containing NEEs as rare elements (REs) are used in OA. These elements cause stress in the plant (Wang et al., 2007a) and increase the amount of SMs (Challaraj et al., 2010a); however, the induced stress can also result in a lower yield. However, OA cannot adequately satisfy the demand for vegetables. An alternative could be to work with the CA techniques with a consideration for yield and nutraceutical quality. Therefore, sustainable agriculture must be promoted. In recent years, researchers have focused on the relationship between fruit and vegetable consumption and on identifying plant compounds that promote health benefits (García-Mier et al., 2013). These compounds are categorized into three groups: alkaloids, polyphenols, and terpenes broadly termed as secondary metabolites (Table 1).

Table 1: Categories of secondary metabolites in plants and their effects on health

\begin{tabular}{lll}
\hline SMs group & Health benefit & Reference \\
\hline Alkaloids & Antioxidant & Herraiz and Galisteo, 2003 \\
& Rheumatoid arthritis & Wang et al., 2007b \\
& Anticancer & Kabashima et al., 2010 \\
& Anti-inflammatory activity & Yang et al., 2007 \\
& Hypertension & Monteiro et al., 2012 \\
Polyphenols & Antimutagenic & Feregrino-Pérez et al., 2011 \\
& Antioxidant & Krinsky and Johnson, 2005 \\
& Anticancer & Fresco et al., 2006 \\
& Antimicrobial & Veloz-García et al., 2010 \\
& Anti-inflammatory, Anti-itch & Sur et al., 2008 \\
& Hypocholesterolemic & Jiao et al., 2010 \\
& Antidiabetic activity & Kobori et al., 2009 \\
Terpenes & Antitumor activity & Lage et al., 2010 \\
& Protection against eye diseases & Krinsky and Johnson, 2005 \\
& Antimicrobial & Mathabe et al., 2008 \\
& Antidiabetic activity & Patil et al., 2011 \\
\hline SMs: secondary metabolites &
\end{tabular}

The role of SMs is to protect the plant from stress. For example, ascorbic acid protects metabolic processes from damage caused by hydrogen peroxide $\left(\mathrm{H}_{2} \mathrm{O}_{2}\right)$ and other toxic oxygen derivatives (Ahmad et al., 2010). Diets based SMs provide benefits by preventing or reducing certain diseases in humans. For example, green tea contains catechins that prevent chronic age-related disorders, such as cardiovascular disease (Hodgson and Croft, 2010), mediate vascular inflammation and atherosclerosis through different actions (i.e., anti-hypertensive, anti-lipemic, antiinflammatory, anti-proliferative and anti-thrombogenic) (Moore et al., 2009; Naito and Yoshikawa, 2009) and prevent the invasion of certain cancers (Khan and Mukhtar, 2008).

\section{Universal Nutrient Solutions in Agriculture}

In 1939, Arnon and Stout published the "essential" elements for plants. Since then, recipes for "universal nutrient solutions" (UNSs) have been introduced, such as the by Hewitt (Steiner, 1961) and Steiner (1984). The latter recipe is widely used in agriculture research and is formed by 12 essential chemical elements: N, P, K, Ca, Mg, S, Fe, Mn, B, $\mathrm{Cu}, \mathrm{Zn}$ and Mo. Currently, UNSs are produced with the maximum 12 essential chemical elements. However, differences exist between various chemical element concentrations. For example, FAO UNS has $34 \%$ more N than of Steiner. In contrast, Kilinc UNS has $70 \%$ and $77 \%$ less $\mathrm{N}$ and $\mathrm{K}$, respectively than Steiner UNS (Table 2). Thus, choosing the most appropriate UNS for research, remains difficult because of variations between solutions. An ionic imbalance of elements in the solution could potentially affect the performance or production of compounds of interest.

Plant nutrition is a complex process that involves these essential elements in addition to carbon, oxygen and hydrogen. In the absence of these elements, plants cannot complete their life cycles (Arnon and Stout, 1939). Therefore, fertilization programs provide optimum amounts of fertilizer to increase visual quality and yield; however, such programs are insufficient. Changes in human populations have caused increases of chronic degenerative diseases, and a new method of producing crops is necessary that can potentiate yields but also produce food with high nutraceutical value capable of contributing to public health.

\section{Nutritional Management: Is it the Right Tool to Increase SMs in Plants?}

The increase in SMs is achieved by manipulating the ionic proportions of the chemical elements in the NS (Table 3). However, use of such techniques requires careful management because synergism or antagonism can be induced between chemical elements and can cause deficiencies or toxicity resulting in a decrease of yield. 
Improving Bioactivity in Plants by Chemical Elements / Int. J. Agric. Biol., Vol. 19, No. 3, 2017

Table 2: Universal nutrient solutions for hydroponics

\begin{tabular}{|c|c|c|c|c|c|c|c|}
\hline Chemical Element & Hoagland and Arnon, 1950 & Hewitt, 1966 & Kilinc, 2007 (1) & Steiner, 1984 & Kilinc, 2007 (2) & FAO, 1990 & Jensen, 1985 \\
\hline \multicolumn{8}{|l|}{$\mathrm{mg} \mathrm{L}^{-1}$} \\
\hline $\mathrm{N}$ & 210 & 168 & 50 & 167 & 150 & $150-225$ & 106 \\
\hline $\mathrm{P}$ & 31 & 41 & 26 & 31 & 31 & $30-45$ & 62 \\
\hline K & 234 & 156 & 66 & 277 & 234 & $300-500$ & 156 \\
\hline $\mathrm{Mg}$ & 48 & 36 & 10 & 49 & 30 & $40-50$ & 48 \\
\hline $\mathrm{Ca}$ & 160 & 160 & 33 & 183 & 100 & $150-300$ & 93 \\
\hline S & 64 & 48 & 5 & 111 & 15 & NA & 64 \\
\hline $\mathrm{Fe}$ & 2.5 & 2.8 & 2.6 & 1.33 & 8 & $3-60$ & 3.8 \\
\hline Mn & 0.5 & 0.55 & 1.6 & 0.62 & 5 & $0.5-1$ & 0.81 \\
\hline B & 0.5 & 0.54 & 0.5 & 0.44 & 1.5 & 0.4 & 0.46 \\
\hline $\mathrm{Cu}$ & 0.02 & 0.064 & 0.66 & 0.02 & 2 & 0.1 & 0.05 \\
\hline $\mathrm{Zn}$ & 0.05 & 0.065 & 1 & 0.11 & 0.3 & 0.1 & 0.09 \\
\hline Mo & 0.01 & 0.048 & 0.066 & 0.048 & 0.2 & 0.05 & 0.03 \\
\hline
\end{tabular}

NA: not available

\section{Plant Nutrition with Macronutrients}

Nitrogen $(\mathrm{N})$ is the only element used as a cation $\left(\mathrm{NH}_{4}^{+}\right)$or anion $\left(\mathrm{NO}_{3}^{-}\right)$. Nitrogen influences growth and morphological development (Gifford et al., 2008), primary and secondary plant metabolism (Giorgi et al., 2009). The link between primary and secondary metabolic pathways in plants is considered to occur through phenylalanine ammonia-lyase (PAL), which explains the concurrent increase of flavonoid activity with increased PAL activity (Lillo et al., 2008). Nitrogen is highly consumed by plants, and non-optimal concentrations of $\mathrm{N}$ can lead to losses of yield.

Productivity is also limited under phosphorus (P) deficiency (Chen et al., 2008) and as part of energy rich molecules such as adenosine triphosphate (ATP), nucleic acids and phospholipids, it is involved in primary metabolism (Wu et al., 2003). The symptoms of plant $\mathrm{P}$ deficiency are the production of anthocyanins and decreases of development.

Potassium $(\mathrm{K})$ is essential for the synthesis of proteins, glycolytic enzymes and for photosynthesis (Hu et al., 2005). It acts as a coenzyme and activates different precursor enzymes of metabolic pathways (Bussakorn et al., 2003), and its partial or total deficiency has been associated with increased antioxidant enzymes (AOEs). Potassium might play a special role in the process of carotenoid biosynthesis by activating several enzymes regulating carbohydrate metabolism as well as the precursors of isopentenyl diphosphate, pyruvate and glyceraldehyde 3-phosphate (Fanasca et al., 2006).

Calcium ions $(\mathrm{Ca})$ have been adopted as a secondary messenger and represent a versatile signaling molecule in eukaryotic organisms (Dodd et al., 2010). It is involved in several plant physiological processes, acts as an indicator and translator, and is present in sensory proteins that decode specific stimuli (Batistič and Kudla, 2012). Low levels of $\mathrm{Ca}$ in the NS increase AOEs levels. However, within the cellular structure, non-optimal concentrations of Ca cause fruit damage; for example, "blossom end rot" in tomato results in the total loss of the product.

Magnesium $(\mathrm{Mg})$ is involved in vital plant functions such as 1) phosphorylation for ATP formation in chloroplasts, photosynthetic fixation of carbon dioxide, protein synthesis, chlorophyll formation, phloem restoring, partitioning and assimilation of photosynthetic products, generation of oxygen reactive forms and photo-oxidation of leaf tissues and activation of enzymes such as ribulose-1.5-diphosphate carboxylase (RuBP) (Cakmak and Yazici, 2010). It is also part of the molecular structure of chlorophyll, and its absence causes severe plant stress that leads to increased AOEs production. In certain cases, the absence of $\mathrm{Mg}$ in the NS reduces carotenes and increases AOEs, such as superoxide dismutase (SOD), peroxidase (POD) and ascorbate peroxidase (APX) (Tewari et al., 2006).

Likely, sulfur (S) is converted to cysteine in plants, the main substrate for the synthesis of compounds that contain S (Nikiforova et al., 2005), such as methionine, glutathione, nicotinamide, phytochelatins and phytoalexins (Rausch and Wachter, 2005).

\section{Plant Nutrition with Micronutrients}

The application of micronutrients in plants has been strengthened, and the effects of these micronutrients on SM production depend mainly on the concentration and type of element (Table 4). Similar to macronutrients, inaccurate concentrations of micronutrients can cause crop damage related to toxicity because plants require micronutrients in small amounts.

Iron $(\mathrm{Fe})$ is an essential element and its absence reduces productivity in photosynthetic organisms (Jeong and Guerinot, 2009). Fe is a co-factor for proteins involved in cellular processes such as respiration, photosynthesis and cell differentiation (Broadley et al., 2012). It is required by AOEs because it catalyzes the reactions of electron transfer (Halliwell, 2006).

Copper $(\mathrm{Cu})$ is part of the structure of certain proteins, mainly those involved in photosynthesis (plastocyanins) and 
respiration (cytochrome oxidase) and in the electron transport chain (Pilon et al., 2006).

Zinc $(\mathrm{Zn})$ is the only metal present in six enzyme categories: oxidoreductases, transferases, hydrolases, lyases, isomerases and ligases (Auld, 2001). Zn is a cofactor of these enzymes groups involved in respiration, photosynthesis and hormone biosynthesis (Broadley et al., 2007).

The role of boron (B) in plants include sugar transport, cell wall synthesis and integrity, lignification, carbohydrate metabolism, ribonucleic acid (RNA), indoleacetic acid, phenolic metabolism, and it is incorporated in the cellular membrane (Ahmad et al., 2009).

Molybdenum (Mo) is necessary in biochemical and physiological processes (Sun et al., 2009) and is an essential component of mononuclear enzymes, metabolic processes and cycles of carbon, $\mathrm{N}$ and $\mathrm{S}$ (Liu et al., 2010). At high concentrations, Mo can induce the production of SMs ( $\mathrm{Yu}$ et al., 2012).

Manganese $(\mathrm{Mn})$ is involved in the metabolism of approximately 35 enzymes (Hebbern et al., 2009), and it acts as a metal catalyst and protein activator (Barber, 2003). Manganese participates in the following processes: activation of enzymes involved in $\mathrm{N}$ metabolism (i.e., glutamine synthase and arginase), gibberellic acid and RNA biosynthesis, polymerase activation and fatty acids biosynthesis (Hansch and Mendel, 2009).

\section{Use of Non-essential and Beneficial Elements}

Beneficial elements cause growth retardation, enzymatic activity changes (Gopal and Rizvi, 2008) and photosynthesis disorders (Ganesh et al., 2008). Beneficial elements are used to increase SMs; for example, the content of $\alpha$-tocopherol, asparagine and tyrosine (Hédiji et al., 2010), isocitrate dehydrogenase (ICDH), citrate synthase (CS), fumarase, malate dehydrogenase (MDH) and phosphoenolpyruvate carboxylase (PEPC) increases in tomato plants (López-Millán et al., 2009) when $100 \mu \mathrm{M} \mathrm{Cd}$ is used in the NS. Hibiscus plants grown in soil with $20 \mathrm{mg}$ $\mathrm{kg}^{-1}$ cobalt (Co), showed increased anthocyanins, and a similar effect occurs when $50 \mathrm{ppm}$ nickel (Ni) is applied in the same crop (Aziz et al., 2007). In bean plants, $0.06 \mathrm{mM}$ mercury $(\mathrm{Hg})$ in the $\mathrm{SN}$ increases the contents of $\alpha$ tocopherol, ascorbic acid and retinol, and this response appears to be concentration dependent (Zengin and Munzuroglu, 2005). Silicon (Si) is often used as a beneficial elements in various crops because its effectiveness. Si increases biomass (Eneji et al., 2008) and provides resistance against plagues (Savvas et al., 2009) and heavy metals (Nwugo and Huerta, 2008). Si induces AOEs production (Soylemezoglu et al., 2009), such as SOD and catalase (CAT), which protect plant tissues (Al-Aghabary et $a l ., 2004)$. In alfalfa plants with an NS that contains $1 \mathrm{mM}$ $\mathrm{Si}$, the content of SOD, CAT and POD increases and glutathione reductase (GR) decreases (Wang et al., 2011a). Selenium (Se) is another BE; however, its role has not been completely defined (Malik et al., 2010). Se promotes resistance to abiotic factors (Yao et al., 2009). For example, when Se is used in the NS of soybean at a concentration of $5 \mu \mathrm{M}$, an increase in SOD, CAT, APX and glutathione peroxidase (GPX) activities is observed (Malik et al., 2012).

\section{Use of Rare Elements}

Rare elements (REs) are homogeneous elements with similar chemical properties and include lanthanides, scandium and yttrium. Their use in agriculture is currently increasing, and mixtures of REs can be found in the market. These REs increase SOD, POD, total phenols (TP) and carotenoid content in corn (Challaraj et al., 2010a), modify plant enzymatic activity (Gopal and Rizvi, 2008), and promote the activation of antioxidant mechanisms such as AOEs or SMs. The effect of rare elements on plants varies depending on the element and its dosage. For instance, cerium (Ce), lanthanum (La) and neodymium $(\mathrm{Nd})$ can increase the yield and fruit quality in certain concentrations and in some crops (Wang et al., 2007a); however, can cause toxicity in high concentrations.

In bean plants, gradually increasing La concentrations of the root NS $\left(0.25,0.5,1,2,4,8\right.$ and $\left.12 \mathrm{mg} \mathrm{L}^{-1}\right)$ results in increase of SOD, APX and GPX (Wang et al., 2011b). Taxol content increase when $1 \mathrm{mM}$ of $\mathrm{Ce}^{4+}$ is applied to cells of Taxus cuspidata (Yang et al., 2009). In rice, the use of $\mathrm{Ce}^{4+}$ in the NS leads to an increase of SOD, CAT and malonyldialdehyde (MDA) (Xu and Chen, 2011). In radish plants, the use of terbium $\left(\mathrm{Tb}^{3+}\right)\left(5 \mathrm{mg} \mathrm{L} \mathrm{L}^{-1}\right)$ increases the activity of ascorbate and decreases guaiacol content (Wang et al., 2009).

Rare elements also increase the absorption of ions that may be beneficial for SM synthesis. For example, $\mathrm{Ce}^{3+}$ usage results in an increase of $\mathrm{K}, \mathrm{Mg}, \mathrm{Ca}, \mathrm{Cu}, \mathrm{Fe}$ and $\mathrm{Mn}$ content (Wang et al., 2008), and are applied to infertile soils to improve the availability of essential elements. Similar to beneficial elements, the increased dosage of rare elements can be toxic to plants.

\section{Towards a New Cocktail of Necessary Nutrients (CNN)}

In current agricultural practices, NS with essential elements, and the optimal EE concentrations required to develop NS for commercial crops are known and have produced increases in yield. However, to develop horticultural functional foods, new techniques that produce higher contents of SMs in crops are necessary. One method is to vary $\mathrm{EE}$ concentrations and another method incorporates non-essential elements such as rare elements in the nutrient solution.

Plants can absorb non-essential elements, and if present in an inadequate range, either in the soil or NS, 
Improving Bioactivity in Plants by Chemical Elements / Int. J. Agric. Biol., Vol. 19, No. 3, 2017

Table 3: Effect of different concentrations of macronutrients in plants for the production of secondary metabolites

\begin{tabular}{|c|c|c|c|c|}
\hline Element & Plant & Doses & Effect & Reference \\
\hline \multirow[t]{7}{*}{$\bar{N}$} & Broccoli & 0 & Flavonoids $\uparrow$ & Jones et al., 2007 \\
\hline & Cabbage & 0 & Flavonoids $\uparrow$ & WeiFeng, 2009 \\
\hline & Lettuce & 0 & Flavonoids $\uparrow$ & Chiesa et al., 2009 \\
\hline & Olive tree & 0 & Flavonoids $\uparrow$ & Fernández-Escobar et al., 2006 \\
\hline & & $9.58 \mathrm{meq} \mathrm{L}^{-1}$ & Mannitol $\uparrow$ & Boussadia et al., 2010 \\
\hline & Tomato & 0 & Flavonoids $\uparrow$ & Simonne et al., 2007 \\
\hline & & $3.25 \mathrm{mM}$ & Carotenoids $\downarrow$ & Khavari-Nejad et al., 2013 \\
\hline \multirow[t]{2}{*}{$\mathrm{P}$} & Lentil & 0 & PC and anthocyanins $\uparrow$ & Sarker and Karmoker, 2011 \\
\hline & Tomato & $0.7 \mathrm{mM}$ & $\beta$ - carotene and xanthophyll $\downarrow$ & Khavari-Nejad et al., 2013 \\
\hline \multirow[t]{4}{*}{ K } & Millet & 0 & $\mathrm{CAT}, \mathrm{GPX}$ and $\mathrm{APX} \uparrow$ & Heidari and Jamshidi, 2011 \\
\hline & Tomato & $4 \mathrm{mM}$ & Carotenoids $\downarrow$ & Schwarz et al., 2013 \\
\hline & $\begin{array}{l}\text { Basil } \\
\text { sunflower }\end{array}$ & $5 \mathrm{mM}$ & $\begin{array}{l}\text { Phenols, rosmarinic acid and anthocyanins } \uparrow \\
\text { soluble solids } \uparrow\end{array}$ & Nguyen et al., 2010 \\
\hline & & $25 \mathrm{Kg} \mathrm{ha}^{-1}$ & $\mathrm{SOD}, \mathrm{CAT}$ and GPX $\uparrow$ & Soleimanzadeh et al., 2010 \\
\hline \multirow[t]{6}{*}{$\mathrm{Ca}$} & Millet & 0 & $\mathrm{POD}$ and $\mathrm{CF} \uparrow$ & Finger et al., 2006 \\
\hline & & $5 \mathrm{mM}$ & $\mathrm{PC} \downarrow$ & \\
\hline & Tomato & $0.1 \mathrm{mM}$ & $\begin{array}{l}\text { SOD and DAR } \uparrow \\
\text { CAT, APX and GR } \downarrow\end{array}$ & Mestre et al., 2012 \\
\hline & Eggplant & 0.5 meq $\mathrm{L}^{-1}$ & Total phenols and PPO $\uparrow$ & Pratima et al., 2002 \\
\hline & Tobacco & $5 \mathrm{mM}$ & Total phenols, POD and PPO $\uparrow$ & Ruiz et al., 2003 \\
\hline & cherry & $80 \mathrm{mM}$ & Phenols, flavonoids, anthocyanins and ascorbic acid $\uparrow$ & Aghdam et al., 2013 \\
\hline \multirow[t]{4}{*}{$\mathrm{Mg}$} & blackberry & 0 & Carotenoids $\downarrow$ & Tewari et al., 2006 \\
\hline & Sunflower & & $\mathrm{SOD}, \mathrm{POD}$ and $\mathrm{APX} \uparrow$ & \\
\hline & Lettuce & 0 & Glutathione, SOD, APX, GPX and CAT & Chou et al., 2011 \\
\hline & & $60 \mathrm{mg} \mathrm{L}^{-1}$ & Lactucopicrin $\uparrow$ & Seo et al., 2009 \\
\hline \multirow[t]{3}{*}{$S$} & Arabidopsis & 0 & $\begin{array}{l}\beta \text {-alanine, putrescence, raffinose, glutamine, } \\
\alpha \text { - tocopherol and } \beta \text {-sitosterol } \uparrow\end{array}$ & Zhang et al., 2011a \\
\hline & Beans & 0 & Carotenoids $\uparrow$ & Juszczuk and Ostaszewska, 2011 \\
\hline & Peas & $200 \mathrm{mg} \mathrm{plant}^{-1}$ & saccharose $\uparrow$ & Scherer et al., 2006 \\
\hline
\end{tabular}

PC: phenolic compounds; CAT: catalase; SOD: superoxide dismutase; GPX: glutathione peroxidase; APX: ascorbate peroxidase; POD: peroxidase; DAR: ascorbate reductase; GR: glutathione reductase; PPO: polyphenol oxidase. $\uparrow$ represents an increase; $\downarrow$ represents a decrease

Table 4: Effect of different concentrations of micronutrients on secondary metabolite production in plants

\begin{tabular}{|c|c|c|c|c|}
\hline Element & Plant & Doses & Effect & Reference \\
\hline \multirow[t]{3}{*}{$\mathrm{Fe}$} & Rapeseed & 0 & $\begin{array}{l}\mathrm{AP}, \mathrm{POD}, \mathrm{SOD} \text { and } \mathrm{AA} \uparrow \\
\mathrm{CAT} \downarrow\end{array}$ & Tewari et al., 2013 \\
\hline & Plum & 0 & $\begin{array}{l}\text { Asparagine, alanine, glutamine, and organic acids } \uparrow \\
\text { SOD and APX } \uparrow\end{array}$ & Jiménez et al., 2011 \\
\hline & sweet potato & $9 \mathrm{mmol} \mathrm{L}^{-1}$ & (1) & Adamski et al., 2012 \\
\hline \multirow[t]{5}{*}{$\mathrm{Cu}$} & Poppy & $2 \mathrm{mmol} \mathrm{L}^{-1}$ & Carotenoids $\uparrow$ & Cambrollé et al., 2011 \\
\hline & grapevine & $2.5 \mathrm{mmol} \mathrm{L}^{-1}$ & Carotenoids $\downarrow$ & Cambrollé et al., 2013 \\
\hline & mustard seed & $50 \mu \mathrm{M}$ & Ascorbate and SOD $\uparrow$ & Feigl et al., 2013 \\
\hline & rice & $50 \mu \mathrm{M}$ & Ascorbate and SOD $\uparrow$ & Thounaojam et al., 2012 \\
\hline & & $100 \mu \mathrm{M}$ & GPX, APX and GR $\uparrow$ & \\
\hline \multirow[t]{3}{*}{$\mathrm{Zn}$} & wheat & $3 \mathrm{mM}$ & $\mathrm{POD}, \mathrm{CAT}$ and $\mathrm{APX} \uparrow$ & Li et al., 2013 \\
\hline & Beetroot & $50 \mu \mathrm{M}$ & $\mathrm{MDH}, \mathrm{PEPC}, \mathrm{ICDH}$ and $\mathrm{CS} \uparrow$ & Sagardoy et al., 2011 \\
\hline & Tomato & $100 \mu \mathrm{mol} \mathrm{L}^{-1}$ & Carotenoids, APX and GR $\uparrow$ & Cherif et al., 2011 \\
\hline \multirow[t]{5}{*}{ B } & Tobacco & 0 & GDH, glucose and fructose, organic acids, phenols and amino acids $\uparrow$ & Beato et al., 2011 \\
\hline & Orange tree & $2.5 \mu \mathrm{M}$ & Carotenoids, saccharose, DHAR and CAT $\uparrow$ & Han et al., 2008 \\
\hline & Carrot & $5 \mu \mathrm{M}$ & $\mathrm{AA} \downarrow$ & Eraslan et al., 2007 \\
\hline & Corn & $4 \mathrm{mM}$ & $\begin{array}{l}\text { SOD and } \mathrm{CAT} \uparrow \\
\mathrm{POD} \downarrow\end{array}$ & Esim et al., 2013 \\
\hline & Linen & $450 \mathrm{mM}$ & PAL, PPO and POD $\downarrow$ & Heidarabadi et al., 2011 \\
\hline \multirow[t]{2}{*}{ Mo } & Glycyrrhiza uralensis Fisch & $5.2 \mathrm{mg} \mathrm{L}^{-1}$ & GA and squalene $\uparrow$ & Wang et al., 2013 \\
\hline & Tomato & $0.5-1 \mathrm{mg} \mathrm{kg}^{-1}$ & Yield & Sandabe and Bapetel, 2008 \\
\hline \multirow[t]{3}{*}{$\mathrm{Mn}$} & Clover & $5.2 \mu \mathrm{M}$ & $\mathrm{GPX} \uparrow$ & Dorling et al., 2011 \\
\hline & Pea & $50 \mu \mathrm{M}$ & GOGAT, CAT and APX $\uparrow$ & Gangwar et al., 2010 \\
\hline & Grape & $30 \mathrm{mM}$ & $\mathrm{PPO}, \mathrm{CAT}$ and POD $\downarrow$ & Mou et al., 2011 \\
\hline
\end{tabular}

AP: alkaline protease; POD: peroxidase; SOD: superoxide dismutase; AA: ascorbic acid; CAT: catalase; APX: ascorbate peroxidase; GPX: glutathione peroxidase; GR: glutathione reductase; MDH: malate dehydrogenase; PEPC: phosphoenolpyruvate carboxylase; ICDH: isocitrate dehydrogenase; CS: citrate synthase; GDH: glutamate dehydrogenase; DHAR: dehydroascorbate reductase; PAL: Phenylalanine ammonia-lyase; GA: glycyrrhizic acid; PPO: polyphenol oxidase; GOGAT: oxoglutarate aminotransferase glutamate. $\uparrow$ represents an increase; $\downarrow$ represents a decrease

stress will result in ROS production. Under normal and primarily under stress conditions, ROS are detoxified by a group of enzymatic antioxidants, such as SOD, APX and CAT, and non-enzymatic antioxidants (Fig. 1), such as 


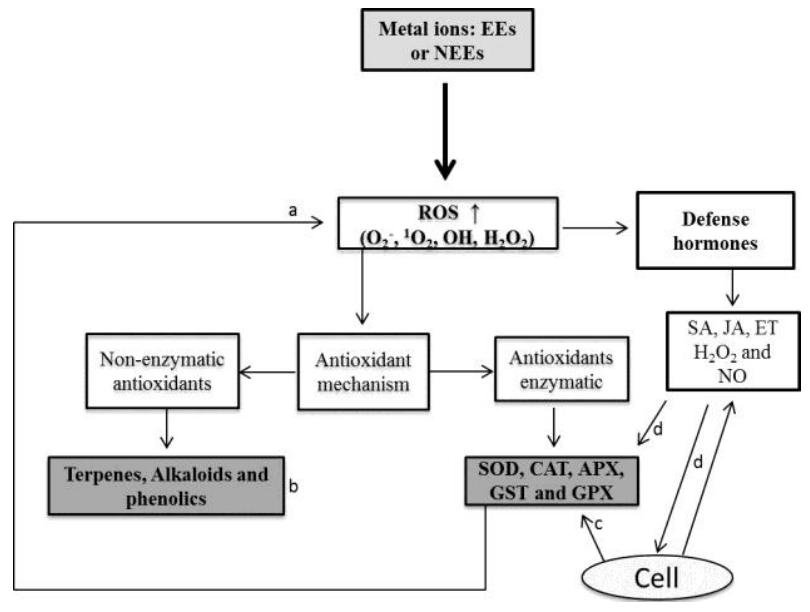

Fig. 1: Metal ion signaling pathway and specific response mechanism: a) degradation/accumulation; b) activation/deactivation of compounds; c) activity increase or decrease; d) regulation of antioxidant enzymes. EEs: essential elements; NEEs: non-essential elements; ROS: reactive oxygen species; SOD: superoxide dismutase; CAT: catalase; APX: ascorbate peroxidase; GST: glutathione S-transferase; GPX: glutathione peroxidase; SA: salicylic acid; JA: jasmonic acid; ET: ethylene; $\mathrm{H}_{2} \mathrm{O}_{2}$ : hydrogen peroxide; $\mathrm{NO}$ : nitric oxide

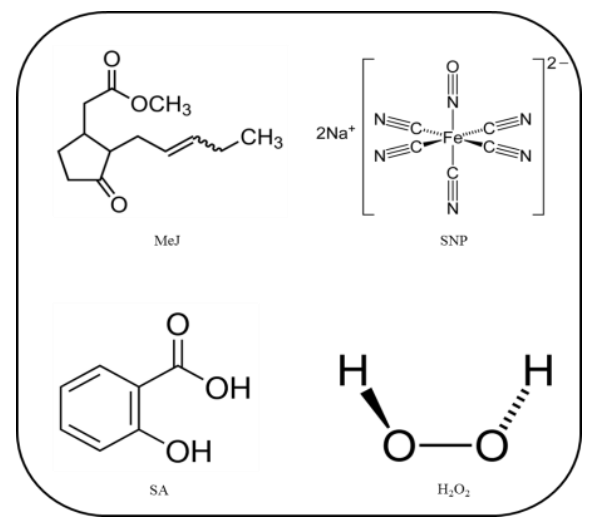

Fig. 2: Elicitor chemical structures, MeJ: methyl jasmonate; SNP: sodium nitroprusside, a donor of nitric oxide; SA: salicylic acid and $\mathrm{H}_{2} \mathrm{O}_{2}$ : hydrogen peroxide

ascorbic acid, glutathione, carotenoids and tocopherols (Miller, 2010).

Non-essential elements (mainly Res) activate plant response genes, alter plasmatic membrane potential (Kenderesová et al., 2012), and induce ROS and Casignaling (Rodrigo-Moreno et al., 2013) in response to ion effects. The production of antioxidant defenses triggered by the presence of certain non-essential elements depends on the type and concentration of the element but also on the plant species (Rodríguez-Serrano et al., 2009). Thus, the antioxidant mechanism can be inhibitory or stimulatory (Schützendübel and Polle, 2002).

It has been shown that if non-essential elements are present in the soil or NS, can be absorbed by plants.
Sheppard et al. (2010) found the following non-essential elements in tomato fruit: $\mathrm{Ag}, \mathrm{As}, \mathrm{Ba}, \mathrm{Cd}, \mathrm{Ce}, \mathrm{Cl}, \mathrm{Co}, \mathrm{Cr}, \mathrm{Cs}$, $\mathrm{La}, \mathrm{Li}, \mathrm{Mo}, \mathrm{Na}, \mathrm{Nb}, \mathrm{Nd}, \mathrm{Ni}, \mathrm{Pb}, \mathrm{Pr}, \mathrm{Rb}, \mathrm{Sb}, \mathrm{Se}, \mathrm{Sm}, \mathrm{Sn}, \mathrm{Sr}$, $\mathrm{Tb}, \mathrm{Th}, \mathrm{Tl}, \mathrm{U}, \mathrm{V}, \mathrm{Y}, \mathrm{Yb}$ and Zr. Similar results were also found by Matos-Reyes et al. (2010), Demir et al. (2010) and Bressy et al. (2012).

Current common practice includes cultivating plants with recipes that contain non-essential elements in the NS. In China, rare elements have been used to increase the quality and yield of crops for several years. However, it is important to consider the adverse effect that NEEs have on crops because their optimal concentration and time of application and effect on each type of crop is currently unknown.

Non-essential elements most likely cause a hormetic effect, which is a plant response to doses with low dosestimulation and high doses-inhibition of growth (Poschenrieder et al., 2013). By including NEEs such as As, $\mathrm{Se}, \mathrm{Cr}, \mathrm{Al}$ and $\mathrm{Pb}$ in the NS, yield increases, and it is likely stimulation in an adaptive compensation process (Poschenrieder et al., 2013). Studies have suggested stressinduced growth mainly because of excess metals; however, few studies have analyzed the physiological state and molecular mechanisms of the stimulant response to accurately assess the action of ions in the plant.

Based on these data, it may be possible to develop a recipe or "cocktail" of nutrients containing essential and nonessential element to increase plant SMs without affecting the yield. Physiologically, ROS can be induced in the plant to activate antioxidant mechanisms, thus generating functional foods. However, it is difficult to calculate the amount of SMs to induce at the expense of yield because an increase in ROS is usually accompanied by plant damage.

\section{NEEs and Elicitors are Necessary for SMs Production}

Several methods exist that increase SMs in plants, such as using elicitors (Table 5). Chemical elicitors, including SA, $\mathrm{JA}, \mathrm{NO}$, and MeJ, may interact with receptors in plants, activating defense response (Ruiz-García and Gómez-Plaza, 2013). For instance, NO is involved in abiotic stress, as are heavy metals (Zheng et al., 2008). NO also interacts with ROS in various ways and may serve as an antioxidant and ROS scavenger during environmental stress (Zheng et al., 2010). Additionally, elevated $\mathrm{NO}$ down regulates $\mathrm{K}^{+} / \mathrm{Cl}^{-}$ influx, and promotes $\mathrm{K}^{+} / \mathrm{Cl}^{-}$efflux and $\mathrm{Ca}^{2+}$ release during stomatal closure (Sokolovski and Blatt, 2004). NO regulates mineral absorption, particularly at concentrations of $50 \mu \mathrm{M}$, and enhances shoot uptake of $\mathrm{Mg}, \mathrm{Cu}, \mathrm{Ca}$ and $\mathrm{Fe}$ (Liu et al., 2015). Moreover, NO regulates genes related to plant growth and ion absorption (Besson-Bard et al., 2009). MeJ is a naturally occurring plant growth regulator that modulates chlorophyll degradation and anthocyanin biosynthesis (Ruiz-García et al., 2012). MeJ has been also involved in $\mathrm{NH}_{4}{ }^{+}$accumulation in rice leaves (Hung and $\mathrm{Kao}, 2007) . \mathrm{NH}_{4}{ }^{+}$is released through the action of $\mathrm{PAL}$, the 
Improving Bioactivity in Plants by Chemical Elements / Int. J. Agric. Biol., Vol. 19, No. 3, 2017

Table 5: Effects of chemical elicitors on plant antioxidant enzymes/secondary metabolites

\begin{tabular}{llll}
\hline Plant & Elicitor $($ dose $)$ & Effect & Reference \\
\hline Tomato & NO: $100 \mu \mathrm{M}$ & Chelate reductase $\uparrow$ & Graziano and Lamattina, 2007 \\
Tomato & NO: $20 \mu \mathrm{M}$ & CAT, POD, SOD and APX $\uparrow$ & Zhao et al., 2011 \\
Tomato & NO: $100 \mu \mathrm{M}$ & Chelate reductase $\uparrow$ & Graziano and Lamattina, 2007 \\
Tomato & NO: $20 \mu \mathrm{M}$ & CAT, POD, SOD and APX $\uparrow$ & Zhao et al., 2011 \\
Tomato & SA: $100 \mu \mathrm{M}$ & CAT and POD $\uparrow$ & Ortega-Ortiz et al., 2007 \\
Tomato & SA: $10 \mathrm{mM}$ & Vitamin C and ${ }^{\circ}$ Brix $\uparrow$ & Javaheri et al., 2012 \\
Tomato & SA: $500 \mu \mathrm{M}$ & Soluble solids $\uparrow$ & Yildirim and Dursun, 2009 \\
Tomato & MeJ: $0.1 \mu \mathrm{M}$ & Quercetin $\uparrow$ & Horbowicz et al., 2011 \\
Strawberry & $\mathrm{MeJ}: 300 \mu \mathrm{M}$ & Resveratrol $\uparrow$ & Wang et al., 2007c \\
Cucumber & $\mathrm{H}_{2} \mathrm{O}_{2}: 1.5 \mathrm{mM}$ & SOD, GH and APX $\uparrow$ & Zhang et al., $2011 \mathrm{~b}$ \\
Cucumber & $\mathrm{H}_{2} \mathrm{O}_{2}: 1.5 \mathrm{mM}$ & POD, DHAR and APX $\uparrow$ & Gao et al., 2010 \\
\hline
\end{tabular}

$\mathrm{H}_{2} \mathrm{O}_{2}$ : hydrogen peroxide; NO: nitric oxide; SA: salcylic acid; MeJ: methyl jasmonate; POD: peroxidase; CAT: catalase; APX: ascorbate peroxidase; SOD: superoxide dismutase; GH: glutathione; DHAR: dehydroascorbate reductase. $\uparrow$ represents an increase; $\downarrow$ represents a decrease

Table 6: Production of bioactive compounds and/or antioxidant enzymes by elicitation in plants grown in soil, in vitro or in substrate

\begin{tabular}{|c|c|c|c|c|}
\hline $\begin{array}{l}\text { Cultivation } \\
\text { Medium }\end{array}$ & Plant & Elicitor & Bioactive Compounds/AOEs(difference from control) & Reference \\
\hline Soil & Artemisia аппиа & $2 \mathrm{mmol} \mathrm{NO}$ & Total chlorophyll, artemisinin content, POD, SOD and CAT $\uparrow$ & Aftab et al., 2012 \\
\hline Soil & Brassicacampestris & $50 \mathrm{mmol} \mathrm{H}_{2} \mathrm{O}_{2}$ & $\mathrm{CAT}$ and MDA $\uparrow$ & Chun-Yan et al., 2007 \\
\hline Soil & Glycine $\max$ & $2 \%\left(\mathrm{SO}_{2}+\mathrm{NO}_{2}\right)$ & $\mathrm{PC} \uparrow$ & Hamid and Jawaid, 2009 \\
\hline Soil & Lycopersicon esculentum & $0.5 \mathrm{mM} \mathrm{SA}$ & Chlorophyll $\uparrow$ & Yildrrm and Dursun, 2009 \\
\hline Soil & Lycopersicon esculentum & $10^{-4} \mathrm{MSA}$ & Lycopene and vitamin $\mathrm{C}=$ & Javaheri et al., 2012 \\
\hline Soil & Syzygium samarangense & $5 \mathrm{mM} \mathrm{H}_{2} \mathrm{O}_{2}$ & Flavonoids, anthocyanins, total phenols and carotenoids $\uparrow$ & Khandaker et al., 2012 \\
\hline Soil & Zea mays & $100 \mathrm{ppm} \mathrm{SA}$ & Chlorophyll $\uparrow$ & Rao et al., 2012 \\
\hline Substrate: UNS & Lycopersicon esculentum & $100 \mu \mathrm{M}$ SNP & Proline, chlorophyll, MDA, CAT, LOX, APX and GPX = & Kazemi, 2012 \\
\hline In vitro & Fagopyrum esculentum & $10^{-6} \mathrm{M} \mathrm{MeJ}$ & Acids: caffeic, gallic, syringic, feluric, coumaric acid, and quercetin $=$ & Horbowicz et al., 2011 \\
\hline In vitro: $\mathrm{NS}$ & Cucumis sativus & $100 \mathrm{M}$ SNP & SOD, CAT, GPX, APX, DHAR, AsA and GSH = & Lin et al., 2012 \\
\hline In vitro & Physalis peruviana & $0.1 \mathrm{mg} \mathrm{L}^{-1} \mathrm{JA}$ or $1 \mathrm{Mm} \mathrm{SA}$ & $4 \square$ - hydroxy-withanolides $\mathrm{E}=$ & Piñeros-Castro et al., 2009 \\
\hline Substrate: UNS & Glycine $\max$ & $100 \mu \mathrm{M}$ SA or SNP & Flavonoids, anthocyanins, LOX and SOD = & Simaei et al., 2012 \\
\hline In vitro & Lycopersicon esculentum & $1 \mathrm{mM} \mathrm{SA}$ & Total chlorophyll and carotenoids totals $=$ & Shahba et al., 2010 \\
\hline Substrate: UNS & Lycopersicon esculentum & $100 \mu \mathrm{M}$ SNP & SOD, POD, CAT y APX = & Zhang et al., 2009 \\
\hline Substrate: UNS & Cucumis sativus & $1.5 \mathrm{mM} \mathrm{H} 2 \mathrm{O} 2$ & SOD, CAT, GSH-PX, GR and AsA = & Zhang et al., 2011b \\
\hline
\end{tabular}

first enzyme in the phenylpropanoid biosynthesis pathway (Hahlbrock and Grisebach, 1979).

Plants produce signaling molecules such as SA, JA and $\mathrm{NO}$, and the content of these molecules increase when the plant is under stress. Compounds such as chitosan, harpin and 1-methylcyclopropane have been also identified, and provide benefits when exogenously applied to the plant. These benefits include protection against plague or diseases or support of metabolism. These compounds mimic the action of signaling molecules such as SA and JA and their derivatives. These also interact with plant receptors that activate defense mechanisms, such as TP and flavonoids (Liu et al., 2005). Signaling molecules such as methyl jasmonate (MeJ), SA, $\mathrm{H}_{2} \mathrm{O}_{2}$ and $\mathrm{NO}$ currently used exogenously to increase the SMs content in crops, and these molecules are known to regulate the production of AOEs and SMs (Fig. 1). These molecules have different characteristics (Fig. 2), but in some crops, these produce similar effects (see Table 5).
In hydroponic crops, the increased SMs in elicited plants are barely noticeable. However, the increase of SMs is significant when elicitors are used in plants growing in soil or compost (Table 6), and Turra et al. (2011) showed that compost contains REs. The increase of SMs may occur because soil contains certain NEEs and REs that helps to activate SM synthesis pathways. Rare elements are involved in plant metabolism and increase ion absorption, protein synthesis, chlorophyll $a$ and $b$ content, plant yield, and enzyme activity (POD and SOD) (Challaraj et al., 2010b).

Plants respond differently to elicitors i.e., certain SMs are activated in certain plants and the same SMs can be deactivated in others (Table 6). Signal perception is the first step in the elicitation process and leads to a transduction cascade by which plants respond to stimuli and activate kinases and produce ROS, ion flow and cytoplasm acidification (Vasconsuelo and Boland, 2007). However, if the plant is elicited and the necessary material (some 
chemical element) is not found in the soil or NS, the expected response to the stimuli will not occur. When the plant is elicited, one of two actions occurs: certain elements classified as non-essential are present in the ion flux, and they can stimulate SM synthesis; or NEEs present in a minimum quantity exert pressure in the cell that favors a secondary metabolism pathway. Plants cultured in substrates or in vitro with NS, even when an elicitor is used, do not indicate an increase in SMs (compared to the non-elicitor control), which may result from missing a certain metabolite biochemical pathway chemical element that is necessary for activation (Table 6). However, the elicitation of plants grown in soil usually produce a favorable response in terms of SM production, which may be explained by the presence of NEEs, such as EBs or REs, in soils, and these NEEs participate directly and indirectly in the production of SMs.

\section{Conclusions}

Plants generate SMs to protect cells from the harmful effects caused by ROS, and SMs also have beneficial health effects. OA produces horticulture products with greater amounts of SMs, but such agricultural techniques are inadequate to satisfy the global demand, whereas the NS used in CA are insufficient to produce fruits and vegetables with high nutraceutical value. The use of a technique that may increase plant SMs, such as varying the ionic EE ratio or adding NEEs in the NS, results in lower yield. Applying only elicitors, such as MeJ, NO and SA, forces the plant to produce SMs but causes lower yields. Certain NEEs can be included in the NS, and elicitors can be applied to plant foliage. Thus, NEEs could enhance ROS production and elicitors could activate antioxidant mechanisms. Thus, the production of ROS and bioactive compounds, such as terpenes, alkaloids and phenols, would be equilibrated.

According to reports found in the literature, the application of elicitors and the presence of NEEs in the NS or soil are necessary to increase and potentiate SM production. Therefore, the coordinated combination of these two techniques is required for the production of SMs. However, ions must be identified that can be added to the NS without being transferred to the edible part of the plants or concentrations of such ions must be determined that are low enough to avoid health damage. In addition, this new cocktail must not have a negative impact on the environment. Thus, the new NS should increase yield and produce food with higher nutraceutical qualities capable of preventing human diseases.

\section{Acknowledgements}

The first author acknowledges the financial support from Universidad Autónoma de Querétaro, Querétaro, México. Additionally, authors thanks to FORDECYT (193512), FOMIX-Qro and Ciencia Basica SEP-CONACYT 2012, for partial support of this research.

\section{References}

Adamski, J.M., R. Danieloski, S. Deuner, E.J.B. Braga, L.A.S. de Castro and J.A. Peters, 2012. Responses to excess iron in sweet potato: impacts on growth, enzyme activities, mineral concentrations, and anatomy. Acta Physiol. Plant., 34: 1827-1836

Aftab, T., M.M. Khan, M. Naeem, M. Idrees, Moinuddin, J.A. Teixeira da Silva and M. Ram, 2012. Exogenous nitric oxide donor protects Artemisia annua from oxidative stress generated by boron and aluminium toxicity. Ecotoxicol. Environ. Safe., 80: 60-68

Aghdam, M.S., A.Y. Dokhanieh, H. Hassanpour and J.R. Fard, 2013. Enhancement of antioxidant capacity of cornelian cherry (Cornus mas) fruit by postharvest calcium treatment. Sci. Hortic., 161: 160164

Ahmad, P., C.A. Jaleel, M.A. Salem, G. Nabi and S. Sharma, 2010. Roles of enzymatic and nonenzymatic antioxidants in plants during abiotic stress. Crit. Rev. Biotechnol., 30: 161-175

Ahmad, W., A. Niaz, S. Kanwal and M.K. Rasheed, 2009. Role of boron in plant growth: A review. J. Agric. Res., 47: 329-338

Al-Aghabary, K., Z. Zhu and Q. Shi, 2004. Influence of silicon supply on chlorophyll content, chlorophyll fluorescence, and antioxidative enzyme activities in tomato plants under salt stress. J. Plant Nutr., 27: 2101-2115

Arnon, D.I. and P.R. Stout, 1939. The essentiality of certain elements in minute quantity for plants with special reference to copper. Plant Physiol., 14: 371-375

Auld, D.S., 2001. Zinc coordination sphere in biochemical zinc sites. Biometals, 14: 271-313

Aziz, E.E., N. Gad and M.N. Badran, 2007. Effect of Cobalt and Nickel on Plant Growth, Yield and Flavonoids Content of Hibiscus sabdariffa L. Aust. J. Basic Appl. Sci., 1: 73-78

Barber, J., 2003. Photosystem II: the engine of life. Quat. Rev. Biophys., 36: 71-89

Batistič, O. and J. Kudla, 2012. Analysis of calcium signaling pathways in plants. Biochim. Biophys. Acta, 1820: 1283-1293

Beato, V.M., M.T. Navarro-Gochicoa, J. Rexach, M.B. Herrera-Rodríguez, J.J. Camacho-Cristóbal, S. Kempa, W. Weckwerth and A. GonzálezFontes, 2011. Expression of root glutamate dehydrogenase genes in tobacco plants subjected to boron deprivation. Plant Physiol. Biochem., 49: 1350-1354

Bennett, A.J., G.D. Bending, D. Chandler, S. Hilton and P. Mills, 2012. Meeting the demand for crop production: the challenge of yield decline in crops grown in short rotation. Biol. Rev., 87: 52-71

Bernal, J., J.A. Mendiola, E. Ibáñez and A. Cifuentes, 2011. Advanced analysis of nutraceuticals. J. Pharmaceut. Biomed., 55: 758-774

Besson-Bard, A., A. Gravot, P. Richaud, P. Auroy, C. Duc, F. Gaymard, L. Taconnat, J.P. Renou, A. Pugin and D. Wendehenne, 2009. Nitric oxide contributes to cadmium toxicity in Arabidopsis by promoting cadmium accumulation in roots and by up-regulating genes related to iron uptake. Plant Physiol., 149: 1302-1315

Boussadia, O., K. Steppe, H. Zgallai, E. Ben, S. Hadj, M. Brahama, R. Lemeur and M.C. Van Labeke, 2010. Effects of nitrogen deficiency on leaf photosynthesis, carbohydrate status and biomass production in two olive cultivars 'Meski' and 'Koroneiki'. Sci. Hortic., 123: $336-342$

Bressy, F.C., G.B. Brito, I.S. Barbosa, L.S.G. Teixeira and M.G.A. Korn, 2012. Determination of trace element concentrations in tomato samples at different stages of maturation by ICP OES and ICP-MS following microwave-assisted digestion. Microchem. J., 109: 145149

Broadley, M., P.I.C. Brown, Z. Rengel and F. Zhao, 2012. Function of nutrients: micronutrients. In: Mineral Nutrition of Higher Plants, pp 141-248. P. Marschner (ed.). Academic Press, Amsterdam, London

Broadley, M.R., P.J. White, J.P. Hammond, I. Zelko and A. Lux, 2007. Zinc in plants. New Phytol., 173: 677-702

Bussakorn, S.M., P.S. Daniel, T.T. Michael and R.T. Mark, 2003. A review of potassium in grapevines with special emphasis on berry accumulation. Aust. J. Grape Wine R., 9: 154-168

Cakmak, I. and A.M. Yazici, 2010. Magnesium: a forgotten element in crop production. Better Crops, 94: 23-25 
Cambrollé, J., E. Mateos-Naranjo, S. Redondo-Gómez, T. Luque and M.E. Figueroa, 2011. Growth, reproductive and photosynthetic responses to copper in the yellow-horned poppy, Glaucium flavum Crantz. Environ. Exp. Bot., 71: 57-64

Cambrollé, J., J.L. García, R. Ocete, M.E. Figueroa and M. Cantos, 2013. Growth and photosynthetic responses to copper in wild grapevine. Chemosphere, 93: 294-301

Challaraj, E.S.E., A.M. Ramachandran, D.A. Ravindran, M. Natesan and S. Maruthamuthu, 2010b. Effect of some rare earth elements on dry matter partitioning, nodule formation and chlorophyll content in Arachis hypogaea L. plants. Aust. J. Crop Sci., 4: 670-675

Challaraj, E.S.E., B. Anandkumar, M. Natesan and S. Maruthamuthu, 2010a. Efficacy of rare earth elements on the physiological and biochemical characteristics of Zea mays L. Aust. J. Crop Sci., 4: 289-294

Chen, Y.F., Y. Wang and W.H. Wu, 2008. Membrane transporters for nitrogen, phosphate and potassium uptake in plants. J. Integr. Plant Biol., 50: 835-848

Cherif, J., C. Mediouni, W.B. Ammar and F. Jemal, 2011. Interactions of zinc and cadmium toxicity in their effects on growth and in antioxidative systems in tomato plants (Solanum lycopersicum). $J$. Environ. Sci., 23: 837-844

Chiesa, A., I. Mayorga and A. Leon, 2009. Quality of fresh cut lettuce (Lactuca sativa L.) as affected by lettuce genotype, nitrogen fertilisation and crop season. Adv. Hortic. Sci., 23: 143-149

Chou, T.S., Y.Y. Chao, W.D. Huang, C.Y. Hong and C.H. Kao, 2011. Effect of magnesium deficiency on antioxidant status and cadmium toxicity in rice seedlings. J. Plant Physiol., 168: 1021-1030

Chun-Yan, M.A., X.U. Xin, H.A.O. Lin and C.A.O. Jun, 2007. Nitrogen dioxide-induced responses in Brassica campestris seedling: the role of hydrogen peroxide in the modulation of antioxidative level and induced resistance. Agri. Sci. China, 6: 1193-1200

Connor, D.J., 2008. Organic agriculture cannot feed the world. Field Crop Res., 106: $187-190$

Dayan, F.E., C.L. Cantrell and S.O. Duke, 2009. Natural products in crop protection. Bioorgan. Med. Chem., 17: 4022-4034

de Costa, F., A.C.A. Yendo, J.D. Fleck, G. Gosmann and A.G. Fett-Neto, 2013. Accumulation of a bioactive triterpene saponin fraction of Quillaja brasiliensis leaves is associated with abiotic and biotic stresses. Plant Physiol. Biochem., 66: 56-62

Demir, K., O. Sahin, Y.K. Kadioglu, D.J. Pilbeam and A. Gunes, 2010 Essential and non-essential element composition of tomato plants fertilized with poultry manure. Sci. Hortic., 127: 16-22

Dodd, A.N., J. Kudla and D. Sanders, 2010. The language of calcium signaling. Ann. Rev. Plant Biol., 61: 593-620

Dorling, S.J., S. Leung, C.W.N. Anderson, N.W. Albert and M.T. McManus, 2011. Changes in 1-aminocyclopropane-1-carboxlate (ACC) oxidase expression and enzyme activity in response to excess manganese in white clover (Trifolium repens L.). Plant Physiol. Biochem., 49: 1013-1019

Eneji, A.E., S. Inanaga, S. Muranaka, J. Li, T. Hattori, P. An and W. Tsuji, 2008. Growth and nutrient use in four grasses under drought stress as mediated by silicon fertilizers. J. Plant Nutr., 31: 355-365

Eraslan, F., A. Inal, A. Gunes and M. Alpaslan, 2007. Impact of exogenous salicylic acid on the growth, antioxidant activity and physiology of carrot plants subjected to combined salinity and boron toxicity. Sci. Hortic., 113: 120-128

Esim, N., D. Tiryaki, O. Karadagoglu and O. Atici, 2013. Toxic effects of boron on growth and antioxidant system parameters of maize (Zea mays L.) roots. Toxicol. Ind. Health, 29: 800-805

Fanasca, S., G. Colla, Y. Rouphael, F. Saccardo, G. Maiani, E. Venneria and E. Azzini, 2006. Evolution of nutritional value of two tomato genotypes grown in soilless culture as affected by macrocation proportions. Hort. Sci., 41: 1584-1588

FAO, 1990. Soilless Culture for Horticultural Crop Production. Food and Agriculture Organization of the United Nations, Rome, Italy

Feigl, G., D. Kumar, N. Lehotai, N. Tugyi, A. Molnár, A. Ördög, A. Szepesi, K. Gémes, G. Laskay, L. Erdei and Z. Kolbert, 2013. Physiological and morphological responses of the root system of Indian mustard (Brassica juncea L. Czern.) and rapeseed (Brassica napus L.) to copper stress. Ecotox. Environ. Safe., 94: 179-189
Feregrino-Pérez, A.A., I. Torres-Pacheco, M. Vargas-Hernández, P.V. Munguía-Fragozo, G.F. Loarca-Piña, S.O. Mendoza-Díaz, R.V Ocampo-Velázquez, E. Rico-García and R.G. Guevara-González, 2011. Antioxidant and antimutagenic activities of Acacia pennatula pods. J. Sci. Ind. Res., 70: 859-864

Fernández-Escobar, R., G. Beltrán, M.A. Sánchez-Zamora, J. GarcíaNovelo, M.P. Aguilera and M. Uceda, 2006. Olive oil quality decreases with nitrogen over-fertilization. HortScience., 41: 215-219

Finger, A.T., A.A. de Bastos, O. Ferrarese-Filho and F.M.L. Lucio, 2006 Role of calcium on phenolic compounds and enzymes related to lignification in soybean (Glycine max L.) root growth. Plant Growth Regul., 49: 69-76

Floros, J.D., R. Newsome, W. Fisher, G.V. Barbosa-Cánovas, H. Chen, C.P. Dunne, J.B. German, R.L. Hall, D.R. Heldman and M.V. Karwe, 2010. Feeding the world today and tomorrow: The importance of food science and technology. Compr. Rev. Food Sci. F., 9: 572-599

Fresco, P., F. Borges, C. Diniz and M.P.M. Marques, 2006. New insights on the anticancer properties of dietary polyphenols. Med. Res. Rev., 26: 747-766

Ganesh, K.S., L. Baskaran, S. Rajasekaran, K. Sumathi, A.L.A. Chidambaram and P. Sundaramoorthy, 2008. Chromium stress induced alterations in biochemical and enzyme metabolism in aquatic and terrestrial plants. Colloid. Surface. B., 63: 159-163

Gangwar, S., V.P. Singh, S.M. Prasad and J.N. Maury, 2010. Modulation of manganese toxicity in Pisum sativum L. seedlings by kinetin. Sci. Hortic., 126: 467-474

Gao, Y., Y.K. Guo, S.H. Lin, Y.Y. Fang and J.G. Bai, 2010. Hydrogen peroxide pretreatment alters the activity of antioxidant enzymes and protects chloroplast ultrastructure in heat-stressed cucumber leaves. Sci. Hort., 126: 20-26

García-Mier, L., R.G. Guevara-González, V.M. Mondragón-Olguín, B.R. Verduzco-Cuellar and I. Torres-Pacheco, 2013. Agriculture and bioactives: achieving both crop yield and phytochemicals. Int. J. Mol. Sci., 14: 4203-4222

Gifford, M.L., A. Dean, R.A. Gutierrez, G.M. Coruzzi and K.D. Birnbaum, 2008. Cell specific nitrogen responses mediate developmental plasticity. P. Natl. Acad. Sci. USA, 105: 803-808

Giorgi, A., A. Mingozzi, M. Madeo, G. Speranza and M. Cocucci, 2009. Effect of nitrogen starvation on the phenolic metabolism and antioxidant properties of yarrow (Achillea collina Becker ex Rchb.). Food Chem., 114: 204-211

Gopal, R. and A.H. Rizvi, 2008. Excess lead alters growth, metabolism and translocation of certainnutrientsin radish. Chemosphere, 70: 1539-1544

Graziano, M. and L. Lamattina, 2007. Nitric oxide accumulation is required for molecular and physiological responses to iron deficiency in tomato roots. Plant J., 52: 949-960

Hahlbrock, K. and H. Grisebach, 1979. Enzymic controls in the biosynthesis of lignin and flavonoids. Annu. Rev. Plant Physiol., 30: 105-136

Halliwell, B., 2006. Reactive species and antioxidants. Redox biology is a fundamental theme of aerobic life. Plant Physiol., 141: 312-322

Hamid, N. and F. Jawaid, 2009. Effect of short-term exposure of two different concentrations of sulphur dioxide and nitrogen dioxide mixture on some biochemical parameter of soybean (Glycine max (L.) Merr.). Pak. J. Bot., 41: 2223-2228

Han, S., L.S. Chen, H.X. Jiang, B.R. Smith, L.T. Yang and C.Y. Xie, 2008. Boron deficiency decreases growth and photosynthesis, and increases starch and hexoses in leaves of citrus seedlings. J. Plant Physiol., 165: 1331-1341

Hansch, R. and R.R. Mendel, 2009. Physiological functions of mineral micronutrients $(\mathrm{Cu}, \mathrm{Zn}, \mathrm{Mn}, \mathrm{Fe}, \mathrm{Ni}, \mathrm{Mo}, \mathrm{B}, \mathrm{Cl})$. Curr. Opin. Plant Biol., 12: 259-266

Hebbern, C.A., K.H. Laursen, A.H. Ladegaard, S.B. Schmidt, P. Pedas, D. Bruhn, J.K. Schjoerring, D. Wulfsohn and S. Husted, 2009. Latent manganese deficiency increases transpiration in barley (Hordeum vulgare). Physiol. Plant., 135: 307-316

Hédiji, H., W. Djebali, C. Cabasson, M. Maucourt, P.B.A. Bertrand, L.B. Zoghlami, C. Deborde, A. Moing, R. Brouquisse, W. Charbi and P. Gallusci, 2010. Effects of long-term cadmium exposure on growth hand metabolomic profile of tomato plants. Ecotox. Environ. Saf., 73: $1965-1974$ 
Heidarabadi, M.D., F. Ghanati and T. Fujiwara, 2011. Interaction between boron and aluminum and their effects on phenolic metabolism of Linumusitatissimum L. roots. Plant Physiol. Biochem., 49: 1377-1383

Heidari, M. and P. Jamshidi, 2011. Effects of salinity and potassium application on antioxidant enzyme activities and physiological parameters in pearl millet. Agric. Sci. Chin., 10: 228-237

Heredia, J.B. and L. Cisneros-Zevallos, 2009. The effects of exogenous ethylene and methyl jasmonate on the accumulation of phenolic antioxidants in selected whole and wounded fresh produce. Food Chem., 115: 1500-1508

Herraiz, T. and J. Galisteo, 2003. Tetrahydro- $\beta$-carboline alkaloids occur in fruits and fruit juice. activity as antioxidant and radical scavengers. $J$. Agric. Food Chem., 51: 7156-7161

Hewitt, E.J., 1966. Sand and Water Culture Methods Used in the Study of Plant Nutrition, $2^{\text {nd }}$ edition. Commonwealth Agricultural Bureau, England

Hoagland, D.R. and D.I. Arnon, 1950. The Water Culture Method for Growing Plants Without Soil. Circular 347, University of California, College of Agriculture, Berkeley, USA

Hodgson, J.M. and K.D. Croft, 2010. Tea flavonoids and cardiovascular health. Mol. Aspects Med., 31: 495-502

Horbowicz, M., G. Chrzanowski, D. Koczkodaj and J. Mitrus, 2011. The effect of methyl jasmonate vapors on content of phenolic compound in seedlings of common buckwheat (Fagopyrum esculentum Moench). Acta Soc. Bot. Pol., 80: 5-9

Hu, Y., J. Fromm and U. Schmidhalter, 2005. Effect of salinity on tissue architecture in expanding wheat leaves. Planta, 220: 838-848

Hung, K.T. and C.H. Kao, 2007. The participation of hydrogen peroxide in methyl jasmonate-induced $\mathrm{NH}_{4}{ }^{+}$accumulation in rice leaves. J. Plant Physiol., 164: 1469-1479

Jahangir, M., I.B. Abdel-Farid, H.K. Kim, Y.H. Choi and R. Verpoorte, 2009. Healthy and unhealthy plants: the effect of stress on the metabolism of Brassicaceae. Environ. Exp. Bot., 67: 23-33

Javaheri, M., K. Mashayekhi, A. Dadkhah and F.Z. Tavallaee, 2012. Effects of salicylic acid on yield and quality characters of tomato fruit (Lycopersicumesculentum Mill.). Int. J.Agric. Crop Sci., 4: 1184-1187

Jensen, M.H. and W.L. Collins, 1985. Hydroponic vegetable production. Hortic. Rev., 7: 483-559

Jeong, G.T. and D.H. Park, 2005. Enhancement of growth and secondary metabolite biosynthesis: Effect of elicitors derived from plants and insects. Biotechnol. Bioprocess Eng., 10: 73-77

Jeong, J. and M.L. Guerinot, 2009. Homing in on iron homeostasis in plants. Trends Plant Sci., 14: 280-285

Jiao, R., Z. Zhang, H. Yu, Y. Huang and Z.Y. Chen, 2010. Hypocholesterolemic activity of grape seed proanthocyanidin is mediated by enhancement of bile acid excretion and up-regulation of CYP7A1. J. Nutr. Biochem., 21: 1134-1139

Jiménez, S., N. Ollat, C. Deborde, M. Maucourt, R. Rellán-Álvarez, M.A. Moreno and Y. Gogorcena, 2011. Metabolic response in roots of Prunus rootstocks submitted to iron chlorosis. J. Plant Physiol., 168: 415-423

Jones, R.B., M. Imsic, P. Franz and B.T. Tomkins, 2007. High nitrogen during growth reduced glucoraphanin and flavonol content in broccoli (Brassica oleracea var. italica) heads. Aust. J. Exp. Agric., 47: 1498-1505

Juszczuk, I.M. and M. Ostaszewska, 2011. Respiratory activity, energy and redox status in sulphur-deficient bean plants. Environ. Exp. Bot., 74 245-254

Kabashima, H., N. Miura, M. Shimizu, W. Shinoda, X. Wang, Z. Wang, S. Takahashi, T. Harada, H. Maruyama, S. Tashiro, T. Ichiyanagi and J. Hasegawa, 2010. Preventive impact of alkaloids with anti-cancer effect extracted from natural herb and the derivatives. Webmed Central Preventive Medicine, 1: WMC00519

Kazemi, N., 2012. Effect of exogenous nitric oxide on alleviating nickelinduced oxidative stress in leaves of tomato plants. Int. J. Agric. Sci., 2: 799-809

Kenderesová, L., J. Staňová, E. Ďurišová, M. Nadubinská, M. Čiamporová and M. Ovečka, 2012. Early $\mathrm{Zn}^{2+}$-induced effects on membrane potential account for primary heavy metal susceptibility in tolerant and sensitive Arabidopsis species. Ann. Bot., 110: 445-459
Khan, N. and H. Mukhtar, 2008. Multitargeted therapy of cancer by green tea polyphenols. Cancer Lett., 269: 269-280

Khandaker, M.M., A.N. Boyce and N. Osman, 2012. The influence of hydrogen peroxide on the growth, development and quality of wax apple (Syzygium samarangense, [Blume] Merrill \& L.M. Perry var. jambu madu) fruits. Plant Physiol. Biochem., 53: 101-110

Khavari-Nejad, R.A., F. Najafi and C. Tofighi, 2013. The Effects of nitrate and phosphate deficiencies on certain biochemical metabolites in tomato (Lycopersicon esculentum Mill. c.v. Urbana V.F.) plant. $J$. Stress Physiol. Biochem., 9: 64-73

Kilinc, S.S., E. Ertan and S. Seferoglu, 2007. Effects of different nutrient solution formulations on morphological and biochemical characteristics of nursery fig trees grown in substrate culture. Sci. Hort., 113: 20-27

Kobori, M., S. Masumoto, Y. Akimoto and Y. Takahashi, 2009. Dietary quercetin alleviates diabetic symptoms and reduces streptozotocininduced disturbance of hepatic gene expression in mice. Mol. Nutr. Food Res., 53: 859-868

Krinsky, N.I. and E.J. Johnson, 2005. Carotenoid actions and their relation to health and disease. Mol. Aspects Med., 26: 459-516

Lage, H., N. Duarte, C. Coburger, A. Hilgeroth and M.J.U. Ferreira, 2010 Antitumor activity of terpenoids against classical and atypical multidrug resistant cancer cells. Phytomedicine, 17: 441-448

Li, X., Y. Yang, L. Jia, H. Chen and X. Wei, 2013. Zinc-induced oxidative damage, antioxidant enzyme response and proline metabolism in roots and leaves of wheat plants. Ecotox. Environ. Safe., 89: 150-157

Lillo, C., U.S. Lea and P. Ruoff, 2008. Nutrient depletion as a key factor for manipulating gene expression and product formation in differen branches of the flavonoid pathway. Plant Cell Environ., 31: 587-601

Lin, Y., Z. Liu, Q. Shi, X. Wang, M. Wei and F. Yang, 2012. Exogenous nitric oxide (NO) increased antioxidant capacity of cucumber hypocotyl and radicle under salt stress. Sci. Hort., 142: 118-127

Liu, H.G., C.X. Hu, X.C. Sun, Q.L. Tan, Z.J. Nie and X.M. Hu, 2010. Interactive effects of molybdenum and phosphorus fertilizers on photosynthetic characteristics of seedlings and grain yield of Brassica napus. Plant Soil, 326: 345-353

Liu, H.X., W.B. Jiang, Y. Bi and Y.B. Luo, 2005. Postharvest BTH treatment induces resistance of peach (Prunus persica L. cv. Jiubao) fruit to infection by Penicillium expansum and enhances activity of fruit defense mechanisms. Postharvest Biol. Tec., 35: 263-269

Liu, S., R. Yang, Y. Pan, M. Ma, J. Pan, Y. Zhao, Q. Cheng, M. Wu, M. Wang and L. Zhang, 2015. Nitric oxide contributes to minerals absorption, proton pumps and hormone equilibrium under cadmium excess in Trifolium repens L. plants. Ecotox. Environ. Safe., 119: 35-46

López-Millán, A.F., R. Sagardoy, M. Solanas, A. Abadía and J. Abadía, 2009. Cadmium toxicity in tomato (Lycopersicon esculentum) plants grown in Hydroponics. Environ. Exp. Bot., 65: 376-385

Malik, J.A., S. Goel, N. Kaur, S. Sharma, I. Singh and H. Nayyar, 2012. Selenium antagonises the toxic effects of arsenic on mungbean (Phaseolus aureus Roxb.) plants by restricting its uptake and enhancing the antioxidative and detoxification mechanisms. Environ. Exp. Bot., 77: 242-248

Malik, J.A., S. Kumar, P. Thakur, S. Sharma, N. Kaur, R. Kaur, D. Pathania, K. Bhandhari, N. Kaushal, K. Singh, A. Srivastava and H. Nayyar, 2010. Promotion of growth in mungbean (Phaseolus aureus Roxb.) by selenium is associated with stimulation of carbohydrate metabolism. Biol. Trace Elem. Res., 143: 530-539

Mathabe, M.C., A.A. Hussein, R.V. Nikolova, A.E. Basson, J.J. Meyer and N. Lall, 2008. Antibacterial activities and cytotoxicity of terpenoids isolated from Spirostachys africana. J. Ethnopharmacol., 116: 194 197

Matos-Reyes, M.N., M.L. Cervera, R.C. Campos and M. De la Guardia, 2010. Total content of As, Sb, Se, Te and Bi in Spanish vegetables, cereals and pulses and estimation of the contribution of these foods to the Mediterranean daily intake of trace elements. Food Chem., 122: $188-194$

Mestre, T.C., F. García-Sánchez, F. Rubio, V. Martínez and R.M. Rivero, 2012. Glutathione homeostasis as an important and novel factor controlling blossom-end rot development in calcium-deficient tomato fruits. J. Plant Physiol., 169: 1719-1727 
Miller, G., N. Suzuki, S. Ciftci-Yilmaz and R. Mittler, 2010. Reactive oxygen species homeostasis and signaling during drought and salinity stresses. Plant Cell Eviron., 33: 453-467

Monteiro, F.S., A.C.L. Silva, I.R.R. Martins, A.C.C. Correia, I.J.L.D. Basílio, M.F. Agra, J. Bhattacharyya and B.A. Silva, 2012 Vasorelaxant action of the total alkaloid fraction obtained from Solanum paludosum Moric. (Solanaceae) involves NO/cGMP/PKG pathway and potassium channels. J. Ethnopharmacol., 141: 895900

Moore, R.J., K.G. Jackson and A.M. Minihane, 2009. Green tea (Camellia sinensis) catechins and vascular function. Brit. J. Nutr., 102: 1790802

Mou, D., Y. Yao, Y. Yang, Y. Zhang, C. Tian and V. Achal, 2011. Plant high tolerance to excess manganese related with root growth, manganese distribution and antioxidative enzyme activity in three grape cultivars. Ecotox. Environ. Saf., 74: 776-786

Naito, Y. and T. Yoshikawa, 2009. Green tea and heart health. $J$. Cardiovasc. Pharm., 54: 385-390

Nguyen, P.M., E.M. Kwee and E.D. Niemeyer, 2010. Potassium rate alters the antioxidant capacity and phenolic concentration of basil (Ocimum basilicum L.) leaves. Food Chem., 123: 1235-1241

Nikiforova, V., J. Kopka, V. Tolstikov, O. Fiehn, L. Hopkins, M.J. Hawkesford, H. Hesse and R. Hoefgen, 2005. Systems rebalancing of metabolism in response to sulfur deprivation, as revealed by metabolome analysis of Arabidopsis plants. Plant Physiol., 138: 304-318

Nwugo, C.C. and A.J. Huerta, 2008. Effects of silicon nutrition on cadmium uptake, growth and photosynthesis of rice plants exposed to lowlevel cadmium. Plant Soil, 311: 73-86

Saw, N.M.M.T., H. Riedel, O. Kütük, K. Ravichandran and I. Smetanska, 2010. Effect of elicitors and precursors on the synthesis of anthocyanin in grape Vitis vinifera cell culture. Energy Rec. J., 1: $189-192$

Ortega-Ortiz, H., A. Benavides-Mendoza, R. Mendoza-Villarreal, H Ramírez-Rodríguez and R.K. De Alba, 2007. Enzymatic Activity in Tomato Fruits as a Response to Chemical Elicitors. J. Mex. Chem. Soc., 51: 141-144

Patil, R., R. Patil, B. Ahirwar and D. Ahirwar, 2011. Current status of Indian medicinal plant with antidiabetic potential: a review. Asian Pac. J. Trop. Biomed., 1: S291-S298

Patra, B., C. Schluttenhofer, Y. Wu, S. Pattanaik and L. Yuan, 2013. Transcriptional regulation of secondary metabolite biosynthesis in plants. Biochim. Biophys. Acta, 1829: 1236-1247

Perez-Vizcaino, F. and J. Duarte, 2010. Phytochemicals and cardiovascular protection: flavonols and cardiovascular disease. Mol. Aspects Med., 31: 478-494

Pilon, M., S.E. Abdel-Ghany, C.M. Cohu, K.A. Gogolin and H. Ye, 2006. Copper cofactor delivery in plant cells. Curr. Opin. Plant Biol., 9: 256-263

Piñeros-Castro, Y., A. Otálvaro-Álvarez and M. Velásquez-Lozano, 2009. Efecto de la aplicación de elicitores sobre la producción de $4 \mathrm{~b}$ hidroxiwithanólido E, en raíces transformadas de Physalis peruviana L. (Effect of application of elicitors on hidroxiwithanólido 4b-E production, in roots transformed of Physalis peruviana L.). Univ. Sci., 14: 23-28

Poschenrieder, C., C. Cabot, S. Martos, B. Gallego and J. Barceló, 2013. Do toxic ions induce hormesis in plants? Plant Sci., 212: 15-25

Pratima, S., B.K. Dube and C. Chaiterjee, 2002. Changes in brinjal (Solanum melongena L.) physiology by calcium deficiency. Ind. $J$. Hortic., 59: 411-415

Ramos-Solano, B., E. Algar, A. García-Villaraco, J. García-Cristóbal, J.A. Lucas-García and F.J. Gutiérrez-Mañero, 2010. Biotic elicitation of isoflavone metabolism with plant growth promoting rhizobacteria in early stages of development in Glycine max var. Osumi. J. Agric Food Chem., 58: 1484-1492

Rao, S.R., A. Qayyum, A. Razzaq, M. Ahmad, I. Mahmood and A. Sher, 2012. Role of foliar application of salicylic acid and l-tryptophan in drought tolerance of maize. J. Anim. Plant sci., 22: 768-772

Rausch, T. and A. Wachter, 2005. Sulfur metabolism: a versatile platform for launching defence operations. Trends Plant Sci., 10: 503-509
Rodrigo-Moreno, A., N. Andrés-Colás, C. Poschenrieder, B. Gunsé, L. Peñarrubia and S. Shabala, 2013. Calcium- and potassium-permeable plasma membrane transporters are activated by copper in Arabidopsis root tips: linking copper transport with cytosolic hydroxyl radical production. Plant Cell Environ., 36: 844-855

Rodríguez-Serrano, M., M.C. Romero-Puertas, D.M. Pazmiño, P.S. Testillano, M.C. Risueño, L.A. Del Rio and L.M. Sandalio, 2009 Cellular response of pea plants to cadmium toxicity: cross talk between reactive oxygen species, nitric oxide, and calcium. Plant Physiol., 150: 229-243

Ruiz, J.M., R.M. Rivero, I. López-Cantarero and L. Romero, 2003. Role of $\mathrm{Ca}$ in the metabolism of phenolic compounds in tobacco leaves (Nicotiana tabacum L.). Plant Growth Regul., 41: 173-177

Ruiz-García, Y. and E. Gómez-Plaza, 2013. Elicitors: a tool for improving fruit phenolic content. Agriculture, 3: 33-52

Ruiz-García, Y., I. Romero-Cáscales, R. Gil-Muñóz, J.I. FernándezFernández, J.M. López-Roca and E. Gómez-Plaza, 2012. Improving grape phenolic content and wine chromatic characteristics through the use of two different elicitors: methyl jasmonate versus benzothiadiazole. J. Agric. Food Chem., 60: 1283-1290

Russell, W. and G. Duthie, 2011. Session 3: Influences of food constituents on gut health Plant secondary metabolites and gut health: the case for phenolic acids. P. Nutr. Soc., 70: 389-396

Sagardoy, R., F. Morales, R. Rellán-Álvarez, A. Abadía, J. Abadía and A.F. López-Millán, 2011. Carboxylate metabolism in sugar beet plants grown with excess Zn. J. Plant Physiol., 168: 730-733

Sandabe, M.K. and U. Bapetel, 2008. The response of tomato (Lycopersicon esculentum) to the application of molybdenum in a semi-arid soil of North Eastern Nigeria. Int. J. Agric. Biol., 10: 97 100

Sarker, B.C. and J.L. Karmoker, 2011. Effects of phosphorus deficiency on accumulation of biochemical compounds in lentil (Lens culinaris Medik.). Bangl. J. Bot., 40: 23-27

Savvas, D., D. Giotis, E. Chatzieustratiou, M. Bakea and G. Patakioutas, 2009. Silicon supply in soilless cultivations of zucchini alleviates stress induced by salinity and powdery mildew infections. Environ. Exp. Bot., 65: 11-17

Scherer, H.W., S. Pacyna, N. Manthey and M. Schulz, 2006. Sulphur supply to peas (Pisum sativum L.) influences symbiotic $\mathrm{N}_{2}$ fixation. Plant Soil Environ., 52: 72-77

Schützendübel, A. and A. Polle, 2002. Plant responses to abiotic stresses: heavy metalinduced oxidative stress and protection by mycorrhization. J. Exp. Bot., 53: 1351-1365

Schwarz, D., G.B. Öztekin, Y. Tüzel, B. Brückner and A. Krumbein, 2013. Rootstocks can enhance tomato growth and quality characteristics at low potassium supply. Sci. Hortic., 149: 70-79

Seo, M.W., D.S. Yang, S.J. Kays, J.H. Kim, J.H. Woo and K.W. Park, 2009. Effects of nutrient solution electrical conductivity and sulfur, magnesium, and phosphorus concentration on sesquiterpene lactones in hydroponically grown lettuce (Lactuca sativa L.). Sci. Hortic., 122: $369-374$

Shahba, Z., B. Amin and Y. Mehdi, 2010. The salicylic acid effect on the tomato (lycopersicum esculentum Mill.) germination, growth and photosynthetic pigment under salinity stress $(\mathrm{NaCl})$. J. Stress Physiol. Biochem., 6: 4-16

Sheppard, S.C., J.M. Long and B. Sanipelli, 2010. Plant/soil concentration ratios for paired field and garden crops, with emphasis on iodine and the role of soil adhesion. J. Environ. Radioactiv., 101: 10321037

Simaei, M., R.A. Khavari-Nejad and F. Bernard, 2012. Exogenous application of salicylic acid and nitric oxide on the ionic contents and enzymatic activities in $\mathrm{NaCl}$-stressed soybean plants. Amer. J. Plant Sci., 3: 1495-1503

Simonne, A.H., J.M. Fuzere, E. Simonne, R.C. Hochmuth and M.R. Marshall, 2007. Effects of nitrogen rates on chemical composition of yellow grape tomato grown in a subtropical climate. J. Plant Nutr. 30: 927-935

Sokolovski, S. and M.R. Blatt, 2004. Nitric oxide block of outwardrectifying $\mathrm{K}+$ channels indicates direct control by protein nitrosylation in guard cells. Plant Physiol., 136: 4275-4284 
Soleimanzadeh, H., D. Habibi, M.R. Ardakani, F. Paknejad and F. Rejali, 2010. Effect of potassium levels on antioxidant enzymes and malondialdehyde content under drought stress in sunflower (Helianthus annuus L.). Amer. J. Agric. Biol. Sci., 5: 56-61

Soylemezoglu, G., K. Demir, A. Inal and A. Gunes, 2009. Effect of silicon on antioxidant and stomatal response of two grapevine (Vitis vinifera L.) rootstocks grown in boron toxic, saline and boron toxic-saline soil. Sci. Hort., 123: 240-246

Stefanelly, D., I. Goodwin and R. Jones, 2010. Minimal nitrogen and water use in horticulture: Effects on quality and content of selected nutrients. Food Res. Int., 43: 1833-1843

Steiner, A., 1961. A universal method for preparing nutrient solutions of a certain desired composition. Plant Soil, 2: 134-154

Steiner, A.A., 1984. The Universal Nutrient Solution. In: International Society for Soilless Culture, pp: 633-649. Proceedings of the Sixth International Congress on Soilless Culture (ed.). Secretariat of ISOSC, The Netherlands

Sun, X.C., C.X. Hu, Q.L. Tan, J.S. Liu and H.G. Liu, 2009. Effects of molybdenum on expression of cold-responsive genes in abscisic acid (ABA)-dependent and ABA-independent pathways in winter wheat under low-temperature stress. Ann. Bot., 104: 345-356

Sur, R., A. Nigam, D. Grote, F. Liebel and M.D. Southall, 2008. Avenanthramides, polyphenols from oats, exhibit anti-inflammatory and anti-itch activity. Arch. Dermatol. Res., 300: 569-574

Tewari, R.K., F. Hadacek, S. Sassmann and I. Lang, 2013. Iron deprivationinduced reactive oxygen species generation leads to non-autolytic PCD in Brassica napus leaves. Environ. Exp. Bot., 91: 74-83

Tewari, R.K., P. Kumar and P.N. Sharma, 2006. Magnesium deficiency induced oxidative stress and antioxidant responses in mulberry plants. Sci. Hortic., 108: 7-14

Thounaojam, T.C., P. Panda, P. Mazumdar, D. Kumar, G.D. Sharma, L. Sahoo and S.K. Panda, 2012. Excess copper induced oxidative stress and response of antioxidants in rice. Plant Physiol. Bioch., 53: 33-39

Turra, C., E.A.N. Fernandes and M.A. Bacchi, 2011. Evaluation on rare earth elements of Brazilian agricultural supplies. J. Environ. Chem. Ecotox., 3: 86-92

Vallverdú-Queralt, A., A. Medina-Remón, I. Casals-Ribes and R.M. Lamuela-Raventos, 2012. Is there any difference between the phenolic content of organic and conventional tomato juices? Food Chem., 130: 222-227

Vasconsuelo, A. and R. Boland, 2007. Molecular aspects of the early stages of elicitation of secondary metabolites in plants. Plant Sci., 172: 861-875

Veloz-García, R., R. Marín-Martínez, R. Veloz-Rodríguez, R. RodríguezGuerra, I. Torres-Pacheco, M.M. González-Chavira, J.L. AnayaLópez, L. Guevara-Olvera, A.A. Feregrino-Pérez and G. LoarcaPiña, 2010. Antimicrobial activities of cascalote (Caesalpinia cacalaco) phenolics-containing extract against fungus Colletotrichum lindemuthianum. Ind. Crop. Prod., 31: 134-138

Wang, C., M. He, W. Shi, J. Wong, T. Cheng, X. Wang, L. Hu and F. Chen, 2011b. Toxicological effects involved in risk assessment of rare earth lanthanum on roots of Vicia faba L. seedlings. J. Environ. Sci., 23: $1721-1728$

Wang, C., Y. Dai, J. Yang, G. Chou, C. Wang and Z. Wang, 2007b. Treatment with total alkaloids from Radix Linderae reduces inflammation and joint destruction in type II collagen-induced model for rheumatoid arthritis. J. Ethnopharmacol., 111: 322-328

Wang, D., Y.X. Pang, W.Q. Wang, C.Y. Wan, J.L. Hou, F.L. Yu, Q.L. Wang, F.B. Liu, X.D. and Zhang, 2013. Effect of molybdenum on secondary metabolic process of glycyrrhizic acid in Glycyrrhiza uralensis Fisch. Biochem. Syst. Ecol., 50: 93-100

Wang, D.F., J.P. Sun, D.H. Du, L.P. Sun, Z.D. Chen and C.H. Xue, 2007a. Degradation of extraction from seaweed and its complex with rare earths for organophosphorous pesticides. J. Rare Earth., 25: 93-99

Wang, L., Q. Zhou and X. Huang, 2009. Photosynthetic responses to heavy metal terbium stress in horseradish leaves. Chemosphere, 77: 10191025
Wang, L., X. Huang and Q. Zhou, 2008. Effects of rare earth elements on the distribution of mineral elements and heavy metals in horseradish. Chemosphere, 73: 314-319

Wang, S.Y., C.T. Chen, C.Y. Wang and P. Chen, 2007c. Resveratrol content in strawberry fruit is affected by preharvest conditions. J. Agric. Food Chem., 55: 8269-8274

Wang, X., Z. Wei, D. Liu and G. Zhao, 2011a. Effects of $\mathrm{NaCl}$ and silicon on activities of antioxidative enzymes in roots, shoots and leaves of alfalfa. Afr. J. Biotechnol., 10: 545-549

WeiFeng, Z., L. XianYong, J. ChongWei, Z. YongSong and F. Ping, 2009. Effects of nitrogen application rates on antioxidant contents and antioxidative activities in Chinese cabbage (Brassica chinensis L.). $J$. Zhejiang Univ., 35: 299-306

Wu, P., L. Ma, X. Hou, M. Wang, Y. Wu, F. Liu and X.W. Deng, 2003. Phosphate starvation triggers distinct alterations of genome expression in Arabidopsis roots and leaves. Plant Physiol., 132: 1260-1271

$\mathrm{Xu}, \mathrm{Q} . \mathrm{M}$. and H. Chen, 2011. Antioxidant responses of rice seedling to $\mathrm{Ce} 4$ under hydroponic cultures. Ecotox. Environ. Safe., 74: 1693-1699

Yang, C.W., T.H. Chuang, P.L. Wu, W.H. Huang and S.J. Lee, 2007. Antiinflammatory effects of 7-methoxycryptopleurineand structure-activity relations of phenanthroindolizidines and phenanthroquinolizidines. Biochem. Biophys. Res. Commun., 354: 942-948

Yang, S., S.H. Lu and Y.J. Yuan, 2009. Cerium elicitor-induced phosphatidic acid triggers apoptotic signaling development in Taxus cuspidata cell suspension cultures. Chem. Phys. Lipids, 159: 13-20

Yao, X., J. Chu and G. Wang, 2009. Effects of selenium on wheat seedlings under drought stress. Biol. Trace Elem. Res., 130: 283-290

Yildirim, E. and A. Dursun, 2009. Effect of foliar salicylic acid applications on plant growth and yield of tomato under greenhouse conditions. Acta Hort. (ISHS), 807: 395-400

Yoshioka, H., K. Mase, M. Yoshioka, M. Kobayashi and S. Asai, 2011. Regulatory mechanisms of nitric oxide and reactive oxygen species generation and their role in plant immunity. Nitric Oxide, 25: 216-221

Yu, W.W., F.L. Cao and G.L. Wu, 2012. Leaf growth and medicinal quality of ginkgo seedling with spraying $\mathrm{Mg}, \mathrm{Zn}$, Mo fertilizers. Acta Bot. Boreal.-Occid. Sin., 32: 1214-1221

Zengin, F.K. and O. Munzuroglu, 2005. Effects of some heavy metals on content of chlorophyll, proline and some antioxidant chemicals in bean (Phaseolus vulgaris L.) seedlings. Acta Biol. Cracov., 47: 157164

Zhang, J., X. Sun, Z. Zhang, Y. Ni, Q. Zhang, X. Liang, H. Xiao, J. Chen and J.G. Tokuhisa, 2011a. Metabolite profiling of Arabidopsis seedlings in response to exogenous sinalbin and sulfur deficiency. Phytochemistry, 72: $1767-1778$

Zhang, X.L., X.F. Jia, B. Yu, Y. Gao and J.G. Bai, 2011b. Exogenous hydrogen peroxide influences antioxidant enzyme activity and lipid peroxidation in cucumber leaves at low light. Sci. Hortic., 129: 656662

Zhang, Y., X. Han, X. Chen, H. Jin and X. Cui, 2009. Exogenous nitric oxide on antioxidative system and ATPase activities from tomato seedlings under copper stress. Sci. Hort.., 123: 217-223

Zhao, J., L.C. Davis and R. Verpoorte. 2005. Elicitor signal transduction leading to production of plant secondary metabolites. Biotech Adv., 23: $283-333$

Zhao, R., J. Sheng, S. Lv, Y. Zheng, J. Zhang, M. Yu and L. Shen, 2011. Nitric oxide participates in the regulation of LeCBF1 gene expression and improves cold tolerance in harvested tomato fruit. Postharvest Biol. Tec., 62: 121-126

Zheng, L.P., B. Zhang, T. Zou, Z.H. Chen and J.W. Wang, 2010. Nitric oxide interacts with reactive oxygen species to regulate oligosaccharideinduced artemisinin biosynthesis in Artemisia аппиа hairy roots. $J$. Med. Plant Res., 4: 758-765

Zheng, L.P., Y.T. Guo, J.W. Wang and R.X. Tan, 2008. Nitric oxide potentiates oligosaccharide-induced artemisinin production in Artemisin апnиа hairy roots. J. Integr. Plant Biol., 50: 49-55

(Received 27 January 2015; Accepted 11 January 2017) 